\title{
ENVIRONMENTAL CHOICES VS. COVID-19 PANDEMIC FEAR - PLASTIC GOVERNANCE RE-ASSESSMENT
}

\author{
MAŁGORZATA GRODZIŃSKA-JURCZAK'ㄹ, ALEKSANDRA KRAWCZYK ${ }^{2}$, \\ ANNA JURCZAK ${ }^{3}$, MARIANNA STRZELECKA ${ }^{4}$, MARIUSZ BOĆKOWSKI ${ }^{5}$, \\ \& MARCIN RECHCIŃSKI ${ }^{6}$
}

${ }^{1}$ Corresponding author: Jagiellonian University, Institute of Environmental Sciences, Gronostajowa 7, 30-387 Kraków, Poland. ORCID: 0000-0003-2084-641X, Email: m.grodzinska-jurczak@uj.edu.pl

${ }^{2}$ Jagiellonian University, Institute of Environmental Sciences, Gronostajowa 7, 30-387 Kraków, Poland. ORCID: 0000-0002-8654-6842, Email:a.krawczyk@doctoral.uj.edu.pl

${ }^{3}$ Jagiellonian University, Institute of Psychology, Ingardena 6, 30-060 Kraków, Poland. ORCID: 00000002-3198-0414, Email:ann.jurczak@gmail.com

${ }^{4}$ Linnaeus University, School of Business and Economics, Kalmar, Sweden. ORCID: 0000-0002-17694753, Email: marianna.strzelecka@lnu.se

${ }^{5}$ Jagiellonian University, Institute of Environmental Sciences, Gronostajowa 7, 30-387 Kraków, Poland. ORCID: 0000-0001-5798-6032, Email: mariusz.bockowski@doctoral.uj.edu.pl

${ }^{6}$ Jagiellonian University, Institute of Geography and Spatial Management, Gronostajowa 7, 30-387, Poland. ORCID: 0000-0002-8793-8047,Email: marcin.rechcinski@uj.edu.pl

ABSTRACT: Alarming plastic production growth worldwide reinforces the public debate about the prevailing environmental crisis, whereby single-use-plastic (SUP) items are considered as by far the most harmful to the environment and public health. Accordingly, European environmental policy aims at eliminating SUP.

Recently, we presented a model of plastic governance that derives from a circular economy approach identifying and taking into consideration perspectives of different actors in the plastic governance, such as producers, wholesalers, shop keepers, consumers, citizen scientists, and academia. Our results illustrate that the vast majority of stakeholders cared for the natural environment and understood the need to phase out SUP from the global economy. We proposed that a knowledge brokerage, 
undertaken by scientists via means of citizen science, as the most effective method to implement elimination policy, as it provides stakeholders with knowledge on why and how to handle SUP issues.

However, at the time of the global COVID-19 pandemic, a plastic governance model required a re-assessment. The perceived role of SUP has changed, as it reflects the health emergency. Namely, due to the health safety reasons stakeholders and consumers are requesting even more SUP than previously. Following up on our data gathered prior to the pandemic, we suggest that under the new circumstances health concerns outweigh the environmental concerns being determined by a shift in the value hierarchization. The paper discusses preliminary results.

KEYWORDS: COVID-19, coronavirus, pandemic, single-use-plastic, SUP, value hierarchization, plastic governance

\section{INTRODUCTION}

While just a few months ago, public discourse was largely focused on environmental matters including climate change and plastic pollution (Kistler and Muffett 2019), today the world's media coverage is largely focused on the ongoing COVID-19 pandemic.

The COVID-19 is the novel respiratory disease, which first became noticeable at the end of December 2019 in Wuhan in the Chinese province of Hubei, later developed into an epidemic in the People's Republic of China in January 2020 and finally spread worldwide, with tremendous speed: on March 7, the WHO reported over 100,000 infected worldwide (3,486 deaths); on March 19, over 200,000 infected (8,778 deaths). Just four days later, on March 23, over 300,000 infected (14,510 deaths), continuously growing. There are (as of March 24, 2020) 190 countries or territories affected: 20 countries in Asia, 21 in the Middle East, 39 in Africa, 57 in Europe, 46 in America and 7 in Australia and Oceania (WHO 2020a). In a large number of countries, the pandemic is now characterized by significant restrictions on public life as well as private life of its citizens.

Meanwhile, the alarming growth of unmanaged plastic waste (in particular Single-Use-Plastic items) and its impact on the environment and human health seems to recede in the background. Each year, the production, recycling, and incineration of plastic items emit about 400 million tons of CO2 (World Economic Forum 2016). The dimension of the related pollution reveals a shocking global scenario anticipating that, given these rates continue, by 2050 the contamination of the natural environment with plastic will reach 12,000 million tons (Geyer, Jambeck, and Law 2017, do Sul and Costa 2014). Despite some success in the area of: (1) legislation (EU Directive 2019/904) and (2) recycling technologies, there is still a need for people to change their mindset and for societies to rethink their attitudes towards plastic usage. Due to a lack of scientific research and solutions for effective communicative strategies, decision-makers struggle to find relevant communication channels and tonalities to increase environmental awareness of the public and persuade people to change their 
behaviors.

Just recently, we've proposed a new environmental governance instrument to tackle this problem - a knowledge communication forum using science communication and citizen science techniques (Cvitanovic et al. 2017), mainly based on public participatory approaches (Lebreton and Andrady 2019, Makri 2017). Hereby, we defined a plastic circular economy as a multi-layered and multi-sectored flow of knowledge, its understanding and brokerage (science communication \& citizen science) among various stakeholders related to plastic. A stakeholder is a person performing many functions (roles) - from any profession in the plastics industry (decision maker, producer, recycler) to the role of consumer. The focus lies on plastic governance, however not merely technically oriented as commonly understood but also, if not above all, cross-disciplinary, using a long term and transformative perspective. Moreover, we suggested that academia should stand ready to address the collective dimension of such a global action (Cvitanovic et al. 2017, Ramaswamy and Gouillart 2010). Hereby, critical knowledge needs to be related to governance aspects of implementing sustainability transformation (plastic governance), followed by an appropriate mechanism to monitor (evaluate) the desired outcomes.

In the era of the COVID-19 pandemic, however, we need to re-assess the model proposed earlier. Health safety standards require increased use of SUP items, which is in a complete contrary to the previous policy aims and public perception of plastic. Moreover, as some consumer groups (e.g. patients, health care personnel) express significantly higher demand for SUP items, this will eventually lead to a further increase of SUP production. Following up our data gathered prior to the pandemic, we propose that given the new pandemic circumstances, health concern will likely outgrow the environmental care, being determined by various factors (e.g. age, stakeholder, consumer type, mission of researchers, cultural aspects or even national circumstances) and eventually lead to a shift in value hierarchization (Bardi et al. 2009, Homer and Kahle 1988).

\section{METHODOLOGY}

We conducted in-depth interviews with stakeholders of the plastic circular economy, to understand whether their health concern due the COVID-19 pandemic has outgrown the environmental care. The qualitative approach allowed gathering a deep and holistic understanding of stakeholders views of how plastic threatens the natural environment, and what has changed during the COVID-19 pandemic. The respondents consisted of representatives of identified stakeholders in plastic circular economy: decision makers, producers, distributors, owners of establishments using plastic items, consumers, ECO-NGOs, waste management institutions, recyclers (see Appendix). All (18) but decision makers (3) interviewees were interviewed twice. In practice, we performed 33 talks. First interview took place before the outbreak of COVID-19 (October-November 2019) and we re-visited with the respondents after the pandemic outbreak (first infections reported in the EU - late January 2020 (WHO 2020b)). The first round interviews were face-to-face, while the second round of talks were conducted 
via Skype and/or cell-phones due to healthy reasons. The interviews were guided by themes such as: perception of the plastic problem, and strategic response to the problem, improving CE in practice, trust towards other actors of CE, needs, expectations, problems, lucks also towards scientific assistance, communication, consultation, steps towards closing the magic loop of plastic circular economy. Interview guide was flexible and easily adjustable to particular respondents in terms of the order of questions and level of details.

The first round of interviews lasted between 1 and 1.5 hours. The second interview was usually shorter and lasted about 30 minutes. Interviews were digitally recorded, and transcribed. Transcripts were then analyzed using open thematic coding of statements divided into two major categories: before and during the COVID-19 outbreak. The coding served in terms of a final categorization aiming to determine possible overlapping areas or causality patterns specific for a group of actors (Weijer, Goldsand, and Emanuel 1999). Additionally, we monitored the number of infected patients in each EU member state, and globally on daily basis to be able to detect the pandemic effect on changing value hierarchy (health concern vs environmental care).

\section{RESULTS}

We interviewed 18 respondents, representatives of plastic governance: (1) decision makers, (2) producers, (3) distributors, (4) owners of establishments using plastic items, (5) consumers, (6) ECO-NGOs, (7) waste management institutions, (8) recyclers (see a full list of respondents at the end of the manuscript). Majority of respondents, significantly more often in the second turn interviewees wanted to stay anonymous, their statements are indicated by numbers in brackets. Each group of interviewees is numbered from [1] - [8], so does indicated in the tables. A full list of institutions they represent is attached in a separate appendix at the end of the manuscript.

The results indicate that all stakeholders in the plastic circular economy perceived plastic, SUPs in particular, a threat to the natural environment. It is worth mentioning, that this attitude towards SUPs and awareness of its potential impacts on the natural environment were within the last years uncommon among producers. They unanimously agreed there is a need for immediate actions to reduce SUP items in the circulation. However they noted many obstacles to accomplishing this goal mainly related to legislation. Specifically, proposed actions in "the EU Directive" and followed national legislation. In particular, producers saw an unrealistic deadline of SUPs ban to meet and still unclear national regulation without the governmental support to smoothen implementation of the EU Directive (Tab. 1).

In the second interview, stakeholders shifted in how they perceived environmental care (conceptualized/operationalized as a threat of plastic, in particular SUPs to the natural environment). Namely, they expressed health concerns due to the COVID-19 outbreak. Moreover, we noted respondents' attention has shifted away from the plastic impacts on the natural environment towards the COVID-19 impacts on public health and economy. Likewise, a general opinion about education to increase public awareness about the natural environment has changed. Respondents agreed that en- 
vironmental issues are not of an immediate importance at the moment and that this view reflects their clients perspective on the issue (Tab. 2). Moreover, environmental actions to impact customers attitudes and behaviour may temporarily lose their appeal, as SUPs acquired a positive image. Ironically, SUPs became the only packaging material accepted by many customers due to the hygienic and health reasons. Bioplastic, multi-used packaging or a system of returnable bottles are not an option in consumers' minds. Importantly, according to our respondents, shopping has increased since the beginning of the COVID-19 outbreak, which results in proportionally higher plastic packaging and plastic waste. Similarly to the SUPs, expanding consumption (less consumption less waste) is not subjected to criticism any longer, mainly because of general recommendation that each household should secure enough food surplus. All these steps are implemented to prevent further expansion of the COVID-19 within the country (Tab. $1 \& 2$ ).

Plastic, distinguished as an environmental problem, was to be efficiently managed. As potential options how to tackle it, respondents enumerated various needs: an improvement of municipal waste management and higher competence of decision makers. What is crucial, second interviews did not mention two issues: a need of the plastic stakeholders network and public consultation which were broadly elaborated during the first talks.

In a long-term perspective, plastic stakeholders expect more advanced financial and merit assistance, mainly from the government. No matter the COVID-19 outbreak, legislation used to be unclear to the stakeholders. They were also discontent of the compensation received from the government. It was verbalized as a real urgency, due to losses, during the pandemic. What is interesting, before the virus plague research support was recognized as worthy by the producers. Those who saw researchers as helpful during the pandemic were ECO-NGOs. 
Table. 1. Interviewees' environmental care as perceptions of the plastic threat to the natural environment prior- the COVID-19 pandemic

\begin{tabular}{|c|c|c|}
\hline THEMATIC AREA & $\begin{array}{l}\text { CATEGORY OF } \\
\text { ISSUES RISEN BY } \\
\text { THE INTERVIEE- } \\
\text { WS }\end{array}$ & CITATION \\
\hline \multirow[t]{2}{*}{$\begin{array}{l}\text { PLASTIC } \\
\text { THREAT PER- } \\
\text { CEPTION }\end{array}$} & A need of education & $\begin{array}{l}\text { "We need to effectively reach society on why and } \\
\text { how plastic is dangerous to the environment and } \\
\text { human health. It should be provided with the de- } \\
\text { tailed guidelines on how to treat the plastic." [2] } \\
\text { "A quality of information needs to be higher. Only } \\
\text { reliable ones can be sent to the public. There is so } \\
\text { much trash and fake-news, that people very often } \\
\text { simply disorientated." [2] } \\
\text { "People require education to increase their aware- } \\
\text { ness toward plastic but it will take a time, in other } \\
\text { words this cannot be a revolution but an evolution } \\
\text { of behavior shift. As a beginning consumers need to } \\
\text { resign from plastic bags, SUP cups to-go." [7] }\end{array}$ \\
\hline & $\begin{array}{l}\text { Increased public } \\
\text { awareness }\end{array}$ & $\begin{array}{l}\text { "People care more and more. Our frequent clients } \\
\text { are having either their own mugs or their ask for } \\
\text { bioplastics cups" [4] } \\
\text { "Well, it's quite obvious that here in my beloved } \\
\text { cafeteria all drinks are served either in glass or } \\
\text { ceramic. We all know that plastic is poisonous" [5] } \\
\text { "The packaging is not a problem. The clients are } \\
\text { the problem due to their eco-requirements. They } \\
\text { want to be certain about food quality but type and } \\
\text { quality of packaging is as important as food qual- } \\
\text { ity" [4] }\end{array}$ \\
\hline
\end{tabular}




\begin{tabular}{|c|c|c|}
\hline \multirow[t]{3}{*}{$\begin{array}{l}\text { HOW TO TACKLE } \\
\text { THE PROBLEM? }\end{array}$} & $\begin{array}{l}\text { Substitutes } \\
\text { (bio-plastics, de- } \\
\text { crease consumption, } \\
\text { returnable bottles, } \\
\text { multi-used packag- } \\
\text { ing) }\end{array}$ & $\begin{array}{l}\text { "Main clients of substitutes are "fancy restaurants" } \\
\text { but due to higher than a SUP price they want to } \\
\text { buy as much as possible for the lowest prize. Cli- } \\
\text { ents of posh restaurants are very sensitive to the } \\
\text { type of plastic they drink/eat from. Just bioplastic } \\
\text { does." [3] } \\
\text { "The EU directive opens a chance to the new } \\
\text { solutions of business model. It should be a kind } \\
\text { of encourage mainly to the consumers of plastic } \\
\text { substitutes and new type of an environmental be- } \\
\text { haviour." [1] } \\
\text { "System of returnable glass bottles works very good } \\
\text { e.g. in Germany. It is very important to make such } \\
\text { a system friendly and easy. ABC easy guideline } \\
\text { should be posted on the machine, but also finan- } \\
\text { cial substitutes are welcomed. We all Poles would } \\
\text { be proud of the national system giving us a feeling } \\
\text { that this is important and collective." [2] }\end{array}$ \\
\hline & $\begin{array}{l}\text { Obstacles: no pro- } \\
\text { ducers in Poland, } \\
\text { all items imported } \\
\text { from the EU \& US, } \\
\text { too high prize to } \\
\text { become common, } \\
\text { no system of regular } \\
\text { composting. Too } \\
\text { low awareness of } \\
\text { what bio-plastic is. }\end{array}$ & $\begin{array}{l}\text { "The problem with plastic is not just SUP but too } \\
\text { high consumption. People simply need to buy less, } \\
\text { so that less waste is produced. Everybody need to } \\
\text { be educated starting from consumer ending up with } \\
\text { recyclers and restaurants owners." [3] }\end{array}$ \\
\hline & $\begin{array}{l}\text { A better control of } \\
\text { plastic producers }\end{array}$ & $\begin{array}{l}\text { "Being in business for } 30 \text { years I've seen too much. } \\
\text { A lot of producers are simply cheating, for example } \\
\text { they mix a bio plastic with a regular plastic giv- } \\
\text { en a label: "biodegradable". They are simply not } \\
\text { checked and not fined." [8] }\end{array}$ \\
\hline
\end{tabular}




\begin{tabular}{|c|c|c|}
\hline $\begin{array}{l}\text { HOW TO IM- } \\
\text { PROVE CIRCU- } \\
\text { LAR ECONOMY } \\
\text { (CE) OF PLASTIC. }\end{array}$ & $\begin{array}{l}\text { Efficient municipal } \\
\text { waste-management. }\end{array}$ & $\begin{array}{l}\text { "The system simply doesn't work. It is leaking. } \\
\text { Personally, I would solve it in a different way. Why } \\
\text { pushing inhabitants to segregate into five types } \\
\text { of materials instead of just two: "wet" and "dry" } \\
\text { waste? Here, at the landfill side we need to segre- } \\
\text { gate all wastes again. It would definitely ease to } \\
\text { sort from scratch, not correcting already segregat- } \\
\text { ed by people." [7] }\end{array}$ \\
\hline \multirow{4}{*}{$\begin{array}{l}\text { HOW EVENTU- } \\
\text { ALLY CLOSE THE } \\
\text { MAGIC LOOP OF } \\
\text { PLASTIC CIRCU- } \\
\text { LAR ECONOMY }\end{array}$} & $\begin{array}{l}\text { Higher competence } \\
\text { of decision makers, }\end{array}$ & $\begin{array}{l}\text { "Although people protest incineration a lot of in- } \\
\text { stallations are needed. If Poland didn't burn wastes } \\
\text { we couldn't tackle the problem. If not the EU we } \\
\text { couldn't have built them on our own but on the } \\
\text { other hand the deadlines to close the landfill sides } \\
\text { is too short. As a country we could not meet the } \\
\text { deadline." [7] }\end{array}$ \\
\hline & $\begin{array}{l}\text { Organising real } \\
\text { public consultation. }\end{array}$ & $\begin{array}{l}\text { "Public consultations in general are fake. Those } \\
\text { who lead them do not accept our recommendations. } \\
\text { And, we producers, are those who know the plastic } \\
\text { from the cradle to the grave. They do not." [2] }\end{array}$ \\
\hline & $\begin{array}{l}\text { Trust towards oth- } \\
\text { er stakeholders of } \\
\text { plastic CE }\end{array}$ & $\begin{array}{l}\text { "MPO is completely not prepared to compose } \\
\text { bio-plastic. They decided to trash it as a mixed } \\
\text { waste. In this way they lose a short term of biodeg- } \\
\text { radation which is the main advantage of bio-plas- } \\
\text { tic." [5] }\end{array}$ \\
\hline & $\begin{array}{l}\text { Setting a network of } \\
\text { plastic stakeholders }\end{array}$ & $\begin{array}{l}\text { "We need a government to make a real network of } \\
\text { all stakeholders of plastic governments. Just to ex- } \\
\text { change our ideas and recommendations and make } \\
\text { it as a kind of consultation body before the legisla- } \\
\text { tion is implemented." [4] }\end{array}$ \\
\hline \multirow[t]{3}{*}{$\begin{array}{l}\text { STAKEHOLDERS' } \\
\text { NEEDS, EXPEC- } \\
\text { TATIONS, LUCK } \\
\text { OF ASSISTANCE } \\
\text { ETC. }\end{array}$} & $\begin{array}{l}\text { A better, more con- } \\
\text { crete legislation. }\end{array}$ & $\begin{array}{l}\text { A very detailed legislation is needed in terms of } \\
\text { bioplasticity. It needs to be excluded from tradi- } \\
\text { tional plastic, so that a user of bio-plastic could } \\
\text { omit from the recycling cost. [2] }\end{array}$ \\
\hline & $\begin{array}{l}\text { A financial support } \\
\text { to the plastic busi- } \\
\text { ness, mainly recy- } \\
\text { clers. }\end{array}$ & $\begin{array}{l}\text { "Recyclers are in trouble due to low quality of plas- } \\
\text { tic materials. It is because of low cultural segrega- } \\
\text { tion but also of producers who do not care much } \\
\text { about the quality of the material they produce } \\
\text { from. Sarcastically, it is financially worth more to } \\
\text { import plastic waste from China or Ukraine than } \\
\text { using our own." [8] }\end{array}$ \\
\hline & $\begin{array}{l}\text { A support from sci- } \\
\text { entists }\end{array}$ & $\begin{array}{l}\text { "We are very opened to scientific data, mainly on } \\
\text { how plastic is dangerous to the environment. We } \\
\text { also would be happy if scientists provide us with a } \\
\text { technical solution on how to recycle effectively var- } \\
\text { ious types of plastic. Otherwise we will always after } \\
\text { economically-developed countries." [2] }\end{array}$ \\
\hline
\end{tabular}


Table. 2. Interviewees' perceptions of the plastic threat to the environment during the COVID-19 pandemic

\begin{tabular}{|c|c|c|}
\hline THEMATIC AREA & $\begin{array}{l}\text { CATEGORY OF IS- } \\
\text { SUES RISEN BY THE } \\
\text { INTERVIEEWS }\end{array}$ & CITATION \\
\hline \multirow[t]{2}{*}{$\begin{array}{l}\text { PLASTIC THREAT } \\
\text { PERCEPTION }\end{array}$} & A need of education & $\begin{array}{l}\text { "Forget the environmental issues. People } \\
\text { are slowly, but steadily more and more } \\
\text { aware of COVID effects. May people stay at } \\
\text { home surfing social media following often } \\
\text { fake news. But in my opinion the followers } \\
\text { are focused just on COVID not any other } \\
\text { danger not to mention the environment" [3] } \\
\text { "Ecology is not mentioned any longer. All } \\
\text { the eco activists hide and they do not pro- } \\
\text { test as they used to. Oceans will be full of } \\
\text { plastic and who cares?" [8] }\end{array}$ \\
\hline & $\begin{array}{l}\text { Increased public awa- } \\
\text { reness }\end{array}$ & $\begin{array}{l}\text { "During the first week of COVID the number } \\
\text { of clients hasn't decreased but they simply } \\
\text { changed. We still have those who are aware } \\
\text { of the pandemic. They ask us to serve ev- } \\
\text { erything in SUP which is in a complete con- } \\
\text { troversy to the client requirements prior to } \\
\text { pandemic, they were very eco." [4] } \\
\text { "Everybody is crazy about SUP packaging } \\
\text { now. They wanna to be almost sterilized } \\
\text { due to health reasons. We are in two weeks } \\
\text { of pandemic. Everything has changed. We } \\
\text { have ca have of the clients then before } \\
\text { COVID-19. Everything is catering." [4] }\end{array}$ \\
\hline
\end{tabular}




\section{HOW TO TACKLE} THE PROBLEM?

\begin{tabular}{|c|c|}
\hline $\begin{array}{l}\text { Substitutes (bio-plas- } \\
\text { tics, decrease con- } \\
\text { sumption, returnable } \\
\text { bottles, multi-used } \\
\text { packaging) }\end{array}$ & $\begin{array}{l}\text { "Less and less restaurants order our pack- } \\
\text { aging forget about substitutes just SUP. The } \\
\text { restaurants owners underline that they have } \\
\text { to guarantee high hygienic standard. Other- } \\
\text { wise they will lose clients." [4] }\end{array}$ \\
\hline \multirow[t]{3}{*}{$\begin{array}{l}\text { Obstacles: no produc- } \\
\text { ers in Poland, all items } \\
\text { imported from the EU } \\
\text { \& US, too high prize } \\
\text { to become common, } \\
\\
\text { no system of regular } \\
\text { composting. Too low } \\
\text { awareness of what } \\
\text { bio-plastic is. }\end{array}$} & $\begin{array}{l}\text { "Ironically, production of plastic increased. } \\
\text { So does the consumption. People are shop- } \\
\text { ping like crazy aiming at storing the food. } \\
\text { Majority of that kind of food is packed in } \\
\text { plastic. We slowly, but steadily we run out } \\
\text { of imported plastic items and cannot order } \\
\text { the new. Nobody cares about plastic threat } \\
\text { to the environment. They are all in fear of } \\
\text { the virus." [3] }\end{array}$ \\
\hline & $\begin{array}{l}\text { "I can see a higher consumption but in total } \\
\text { the waste tonnage is lower than before pan- } \\
\text { demic. This is due to leaving the big cities, } \\
\text { returning to people's original place of living. } \\
\text { We still cannot inventerize the amount of } \\
\text { segregated wastes as it is collected month- } \\
\text { ly." [7] }\end{array}$ \\
\hline & $\begin{array}{l}\text { "Contrary to the rest of EU countries e.g. } \\
\text { U.K. citizens can afford the catering meals. } \\
\text { The number of clients hasn't not decreased } \\
\text { as in our company. These is an combination } \\
\text { of economic level as well as cultural behav- } \\
\text { ior (cooking or not cooking at home)"[4] }\end{array}$ \\
\hline $\begin{array}{l}\text { A better control of } \\
\text { plastic producers }\end{array}$ & $\begin{array}{l}\text { "There is no control at the moment. Produc- } \\
\text { ers of various plastic are simply producing } \\
\text { what is really needed like e.g. ingredients of } \\
\text { masks, gloves, SUP catering" [2] }\end{array}$ \\
\hline
\end{tabular}




\begin{tabular}{|c|c|c|}
\hline $\begin{array}{l}\text { HOW TO IMPROVE } \\
\text { CIRCULAR ECONOMY } \\
\text { (CE) OF PLASTIC. }\end{array}$ & $\begin{array}{l}\text { Efficient municipal } \\
\text { waste-management. }\end{array}$ & $\begin{array}{l}\text { "The landfill and the incineration needs to } \\
\text { work. We gather trash as we used to. But we } \\
\text { can assess that the quality of segregation } \\
\text { lowered. They don't think of segregation, } \\
\text { having so much shopping, and they simply } \\
\text { don't care about segregation any longer." } \\
\text { [2] }\end{array}$ \\
\hline \multirow{4}{*}{$\begin{array}{l}\text { HOW EVENTUALLY } \\
\text { CLOSE THE MAGIC } \\
\text { LOOP OF PLASTIC } \\
\text { CIRCULAR ECONOMY }\end{array}$} & $\begin{array}{l}\text { Higher competence of } \\
\text { decision makers, }\end{array}$ & $\begin{array}{l}\text { "There is complete chaos. The deputy of the } \\
\text { Ministry of the Environment got infected, } \\
\text { the other is probably focused on COVID. All } \\
\text { decision makers are immersed by the pan- } \\
\text { demic. The deputy of the Ministry of Health } \\
\text { recommended a need of keeping hygiene, } \\
\text { not just washing the hands but also about } \\
\text { eating" [8] }\end{array}$ \\
\hline & $\begin{array}{l}\text { Organising real public } \\
\text { consultation. }\end{array}$ & Issue not mentioned by the interviewee \\
\hline & $\begin{array}{l}\text { Trust towards other } \\
\text { stakeholders of plastic } \\
\text { CE }\end{array}$ & $\begin{array}{l}\text { "I have a feeling that pandemic is not a } \\
\text { good time for common trust. On one hand } \\
\text { we collect money for the hospitals but for } \\
\text { others so many producers and shopkeepers } \\
\text { cheat. Cheat clients, cheat producers, cheat } \\
\text { distributors" [3] }\end{array}$ \\
\hline & $\begin{array}{l}\text { Setting a network of } \\
\text { plastic stakeholders }\end{array}$ & Issue not mentioned by the interviewee \\
\hline
\end{tabular}




\begin{tabular}{|c|c|c|}
\hline \multirow[t]{3}{*}{$\begin{array}{l}\text { STAKEHOLDERS' } \\
\text { NEEDS, EXPECTA- } \\
\text { TIONS, LUCK OF AS- } \\
\text { SISTANCE ETC. }\end{array}$} & $\begin{array}{l}\text { A better, more con- } \\
\text { crete legislation. }\end{array}$ & $\begin{array}{l}\text { "We are a bit disoriented. We would be } \\
\text { happy to provide the hospitals with food ca- } \\
\text { tering even in lower price than before pan- } \\
\text { demic, but there is no regulation on what } \\
\text { packaging can be used due to the health } \\
\text { reasons" [4] }\end{array}$ \\
\hline & $\begin{array}{l}\text { A financial support } \\
\text { to plastic business, } \\
\text { mainly recyclers. }\end{array}$ & $\begin{array}{l}\text { "There is no financial support of the gov- } \\
\text { ernment. All producers and recyclers are } \\
\text { suffering from lower income. The offer they } \\
\text { give is not enough having in mind that } \\
\text { many of us are simply based on not only } \\
\text { polish but also foreign clients. Personally, I } \\
\text { sell recycling machines to Italy, Spain and } \\
\text { Germany. And now everything is stopped" } \\
\text { [8] }\end{array}$ \\
\hline & $\begin{array}{l}\text { A support from scien- } \\
\text { tists }\end{array}$ & $\begin{array}{l}\text { "People think that climate crisis and plastic } \\
\text { crisis is no longer happening. They are mis- } \\
\text { taken. Everything is connected. COVID-19 } \\
\text { results in health of people, that's the first } \\
\text { symptom, but consumption behavior is also } \\
\text { completely altered and depending on the } \\
\text { economic status of the country/consumer. } \\
\text { Less or more plastic is produced" } 6 \text { ] }\end{array}$ \\
\hline
\end{tabular}

\section{DISCUSSION}

Researchers have emphasized that the natural environment must always be viewed and investigated in relation to people (Nisbet and Zelenski 2013, Seymour 2016). Interactions between people and the natural environment represent a complex system. On one hand natural environment impacts people's actions, while on the other hand people also try to change elements of the natural environment to suit their needs. Importantly, when dealing with perceptions, attitudes, and behaviors deployed in relation to the natural environment, time dimension must be taken into account (Moser and Uzzell 2002). That is, when time is added to the equation, contextual factors may give rise to a situation in which certain values will be temporarily of more importance and relevance than others (Caverni, Fabre, and Gonzalez 1990). For instance, the value of prosperity may be more relevant than the value of sustainability or the value of equality.

Our results show that given the increasing health concerns due to the COVID-19 pandemic, environmental care loses its priority position in the value hierarchy. As noted earlier, people tend to reshuffle prioritized values in unusual situations, which means that values we tend to view as compatible, may indeed stand in conflict in specific situations. Moreover, not all values are considered to be of equal importance. The individual weighting of the value depends on the situation and / or culture in individual cases.

Our results indicate that given the new circumstances the pandemic threat has clearly outgrown the perceived threat of plastic, indicating a sudden shift in the hierarchization of values (Bardi et al. 2009, Homer and Kahle 1988), where health is 
considered as a value disclosing environmental care which shows a clear decrease in perceived importance. Following the attitudes and responses given, plastic (SUPs in particular) has scaled a new dimension in consumers' perception (Belch and Belch 2012, Weber and Hsee 1998) mainly due to the hygiene concerns and health risk.

What might be of concern, a clear decline of the need for a plastic stakeholders network and public consultation could be observed among respondents. Also the recognition of academia as an important support decreased, at least in the environmental issues. Meanwhile a lack of proper plastic governance has been raised, requiring an improvement of municipal waste management, clear legislation, higher competence of decision makers and advanced financial and merit assistance due to pandemic related economic losses.

In this sense, we see a clear need to further monitor, observe and assess the prevailing trend, above all, the permanence and the evolution of this phenomenon. We suggest two possible scenarios: (1) the decrease of the pandemic threat will implicate a return to the "old" value system where environmental care does not appear in contrast to health care, (2) the experience of the sudden shift in the value hierarchization will cause long-term "damage" to already considerably high environmental care, as health and individual needs will be still perceived as standing in contradiction to the needs of the environment.

\section{CONCLUSIONS/RECOMMENDATIONS}

Given the concerning trend, we see more than ever the urgent need for a knowledge based debate among plastic stakeholders. With new challenges derived from post-pandemic socioeconomic structures, uncertainty will rise while individuals' needs will change. For the time being, companies and entire industries run into economic difficulties, politics are facing a multidimensional crisis (McKibbin and Fernando 2020, Bénassy-Quéré et al. 2020). Many of the already low financial funds intended for plastic reduction are now likely to be diverted to combat the corona pandemic and related economic consequences. Given the current trend, the plastic industry, under the pressure of several laws prohibiting single-use-plastic usage, already started progressive lobbying in favor of lost interests. The role of citizen science (Lebreton and Andrady 2019, Makri 2017) as a driver of knowledge co-creation among different stakeholder groups becomes crucial. Scientists urgently need to acknowledge their ethical obligation to become active as knowledge brokers enabling a common goal-oriented debate among politicians, producers, and others, including the broader public (Dobbins et al. 2009, von Malmborg 2004). Plastic is not only a luxury problem which concerns when everything else is solved. The "corona crisis" is more immediate than the environmental crisis because the damage is now present and very visible.

What is certain, our world will not be the same after the pandemic. In this respect, the crisis poses a threat but also an opportunity to rethink the basic questions of what we value in life and how these values are connected with each other, it is now a matter of developing a new value system, where we understand that our health is 
clearly connected and dependent of the health of our planet. The already initiated sustainable transition towards plastic-free economies is to be continued and the implementation of the developed model of knowledge co-creation and brokerage seems more urgent than ever before.

FUNDING: This research received no external funding.

CONFLICT OF INTEREST: The authors declare no conflict of interest.

ACKNOWLEDGEMENTS: We thank all interviewees for their openness in the pandemia time, to share their experiences with us. The following manuscript was covered by subsidy of Jagiellonian University No. N18/DBS/000003.

\section{REFERENCES}

Bardi, A., J. A. Lee, N. Hofmann-Towfigh, and G. Soutar. 2009. “The Structure of Intraindividual Value Change." Journal of Personality and Social Psychology 97(5): 913929. DOI: $10.1037 / \mathrm{a} 0016617$.

Belch, George Edward, and Michael A. Belch. 2012. Advertising and Promotion: An Integrated Marketing Communications Perspective. New York: McGraw-Hill/Irwin.

Bénassy-Quéré, Agnès, Ramon Marimon, Jean Pisani-Ferry, Lucrezia Reichlin, Dirk Schoenmaker, and Beatrice Weder di Mauro. 2020. "COVID-19: Europe needs a catastrophe relief plan.” Pp. 128-135 in Mitigating the COVID Economic Crisis: Act Fast and Do Whatever It Takes, edited by R. Baldwin and B. Weder Di Mauro. London: Centre for Economic Policy Research.

Cvitanovic, C., R. Cunningham, A. M. Dowd, S. M. Howden, and E. I. van Putten. 2017. "Using Social Network Analysis to Monitor and Assess the Effectiveness of Knowledge Brokers at Connecting Scientists and Decision-Makers: An Australian case study." Environmental Policy and Governance 27(3): 256-269. DOI: 10.1002/eet.1752.

Directive (EU) 2019/904 of the European Parliament and of the Council of 5 June 2019 on the reduction of the impact of certain plastic products on the environment.

do Sul, J. A. I., and M. F. Costa. 2014. "The present and future of microplastic pollution in the marine environment." Environmental Pollution 185: 352-364. DOI: 10.1016/j.envpol.2013.10.036.

Dobbins, M., P. Robeson, D. Ciliska, S. Hanna, R. Cameron, L. O’Mara, K. DeCorby, and S. Mercer. 2009. "A description of a knowledge broker role implemented as part of a randomized controlled trial evaluating three knowledge translation strategies." Implementation Science 4. DOI: 10.1186/1748-5908-4-23.

Geyer, R., J. R. Jambeck, and K. L. Law. 2017. "Production, use, and fate of all plastics ever made.” Science Advances 3(7). DOI: 10.1126/sciadv.1700782.

Homer, P. M., and L. R. Kahle. 1988. "A Structural Equation Test of the Value Attitude Behavior Hierarchy.” Journal of Personality and Social Psychology 54(4): 638-646. DOI: 10.1037/0022-3514.54.4.638. 
Kistler, Amanda , and Carroll Muffett. 2019. Plastic \& Climate: The Hidden Costs of a Plastic Planet. URL: ciel.org/plasticandclimate/

Lebreton, L., and A. Andrady. 2019. "Future scenarios of global plastic waste generation and disposal." Palgrave Communications 5: XX-XX. doi: 10.1057/s41599018-0212-7.

Maiese, Michelle. 2003. “Moral or Value Conflicts.” Pp. XX-XX in Beyond Intractability, edited by G. Burgess and H. Burgess. Boulder: Conflict Information Consortium, University of Colorado.

Makri, Anita 2017. “Ocean plastics from Haiti's beaches turned into laptop packaging.” New Scientist (3130). URL: https://www.newscientist.com/article/2134334-ocean-plastics-from-haitis-beaches-turned-into-laptop-packaging/

McKibbin, Warwick and Roshen Fernando. 2020. “The Global Macroeconomic Impacts of COVID-19: Seven Scenarios.” CAMA Working Paper 19/2020 (February 2020). URL: https://cama.crawford.anu.edu.au/sites/default/files/publication/cama crawford_anu_edu_au/2020-03/19_2020_mckibbin_fernando_0.pdf

Moser, G, and D Uzzell. 2002. “Environmental psychology.” Pp. XX-XX in Comprehensive Handbook of Psychology, Volume 5: Personality and Social Psychology, edited by T. Millon and M. J. Lerner. New York: John Wiley \& Sons.

Nisbet, E. K., and J. M. Zelenski. 2013. “The NR-6: a new brief measure of nature relatedness.” Frontiers in Psychology no. 4. doi: 10.3389/fpsyg.2013.00813.

Ramaswamy, W., and F. Gouillart. 2010. The Power of Co-Creation : Build It with Them to Boost Growth, Productivity, and Profits: Simon \& Schuster, FreePress.

Seymour, V. 2016. “The Human-Nature Relationship and its impact on Health: A Critical Review.” Frontiers in Public Health 4. DOI: 10.3389/fpubh.2016.00260.

von Malmborg, Fredrik. 2004. "Networking for knowledge transfer: towards an understanding of local authority roles in regional industrial ecosystem management." Business Strategy and the Environment 13(5):334-345. DOI: 10.1002/bse.419.

Weber, E. U., and C. Hsee. 1998. "Cross-cultural differences in risk perception but cross-cultural similarities in attitudes towards perceived risk." Management Science 44(9): 1205-1217. DOI: 10.1287/mnsc.44.9.1205.

Weijer, C., G. Goldsand, and E. J. Emanuel. 1999. "Protecting communities in research: current guidelines and limits of extrapolation.” Nature Genetics 23(3): 275-280. DOI: $10.1038 / 15455$.

WHO. 2020a. “Coronavirus disease (COVID-2019) situation reports.” URL: https:// www.who.int/emergencies/diseases/novel-coronavirus-2019/situation-reports

WHO. 2020b. Novel Coronavirus (2019-nCoV) Situation Report 5; 25 January 2020. URL: $\quad$ https://www.who.int/docs/default-source/coronaviruse/situation-reports/20200125-sitrep-5-2019-ncov.pdf?sfvrsn=429b143d_8

World Economic Forum. 2016. The New Plastics Economy - Rethinking the future of plastics. World Economic Forum, Ellen MacArthur Foundation and McKinsey \& Company. 


\section{A list of institutions respondents of the study represent}

(1) Decision Makers: Deputies of the Ministry of the Environment and directors of Dpt. of waste management, The City Council of Kraków,

(2) Producers (Synthos Group, Alpla - Opakowania z Tworzyw Sztucznych, Ventures Poland; Basf Polska sp.z.o. - bioplastic producers),

(3) Distributors (DIS-PACK Opakowania, Pakler),

(4) Owners of establishments using plastic items (Danone, Happy Diet, caterings, Costa Coffee, shops, Manao, LasVeges, Ramen restaurants),

(5) ECO-NGOs (Greenpeace CEE/Polska),

(6) Waste management institutions (MPO, landfill of Kraków City),

(7) Recyclers (MIKI Recycling, PTS Rabka, Związek Przetwórców Tworzyw Sztucznych, Polska Izba Odzysku i Recyklingu Opakowań, Zakłady Przetwórstwa Tworzyw Sztucznych sp. z.o.o, Kłaj, K\&K Recycling System, Bochnia, Lesser Poland voivodship.

\section{BIOGRAPHICAL NOTE}

Małgorzata Grodzińska-Jurczak, a professor of biology currently works on the social determinants of nature protection, science communication and citizen science. She broadly publishes, teaches in and outside university as well as popularizes results of her studies. An important perspective of her work is popularising environment-related knowledge.

Aleksandra Krawczyk, her professional experience is linked to the development of successful communication strategies and implementation of marketing methods in various industries up to sustainable development aid in the NGO sector. Currently, Aleksandra studies at the Doctoral School of Social Sciences, Jagiellonian University and focuses on socio-psychological and behavioral aspects of the European Strategy for Plastics in a Circular Economy.

Anna Jurczak, studies Psychology at the Jagiellonian University. She is interested in the cognitive-social correlates of human behaviour, and animal-assisted therapy (kinesiotherapy). Anna often gets involved in psychology-based research and social campaigns. She cannot remain indifferent to the changes taking place in our environment, which is why she actively takes part in eco projects too.

Marianna Strzelecka, a researcher and lecturer in tourism studies at Linnaeus University in Sweden, is broadly interested in resident perceptions of and attitudes towards institutionalized nature protection in rural nature-tourism destinations (primarily of Central and Eastern Europe). She is particularly interested in concepts such as sense of justice, institutional trust, environmental identity, and place attachment and nature connectedness in the aforementioned context.

Marcin Rechciński, a geographer, working primarily on social aspects of nature conservation. His $\mathrm{PhD}$ project is focused on conflicts around protected areas, contributing to current theories of nature conservation. Moreover, he develops various applications of participatory mapping in a context of nature conservation. He teaches mostly environmental conditions of spatial planning. Head of the two research projects of National Science Centre, Poland.

Mariusz Boćkowski, MSc in environmental protection (environmental biology). He has multiple professional experience in the NGO sector related to nature conservation and now is working back in academia dealing with social and economic aspects of nature conservation. Presently he conducts $\mathrm{PhD}$ 
research on the use of the concept of ecosystem services in nature governance with focus on creation and management of national parks.

OPEN ACCESS: This article is distributed under the terms of the Creative Commons Attribution Non-commercial License (CC BY-NC 4.0) which permits any non-commercial use, and reproduction in any medium, provided the original author(s) and source are credited.

ARTICLE HISTORY: Received 2020-03-31 / Accepted 2020-04-06 
